\title{
Fusion rate of a PEEK TLIF cage according to the addressed spinal segment - a retrospective analysis
}

\author{
Jung $\mathrm{S}^{1 *}$, Breitenfelder $\mathrm{M}^{1}$, Niggemann $\mathrm{H}^{2}$, Stöve $\mathrm{J}^{1}$ and Hasan $\mathrm{A}^{3}$ \\ ${ }^{1}$ St. Marienkrankenhaus, Orthopaedic and spine surgery, Ludwigshafen on the Rhine, Germany \\ ${ }^{2}$ Diploma-Statistician at p-Wert, Germany \\ ${ }^{3}$ Signus Medizintechnik, Clinical Affairs, Germany
}

\begin{abstract}
Object: Lumbar Fusion is a successful operative possibility to treat lumbar degenerative diseases. The literature describes fusion rates of $90 \%$. This study investigated the rates of lumbar fusion in two different segments in the lower spine.

Methods: This retrospective study included patients who were treated by transforaminal lumbar interbody fusion (TLIF) from $2009-2012$ in the orthopaedic and trauma surgery at St. Marienkrankenhaus hospital in Ludwigshafen. The fusion rate of 48 Segments and the correlation between fusion und segment were radiographically examined. The clinical outcome was measured from 39 patients by VAS and ODI and was compared with the fusion rate.

Results: The fusion rate in L3/4 was 33,3\% and in L4/5 15,2\%. There was no correlation between fusion and segment. The clinical evaluation showed an average improvement in VAS of 4,5. The ODI showed an average improvement of 31,1\%. There was a significant difference between preoperative VAS and ODI to follow-up. The clinical outcome compared to the fusion showed no significant deviation.
\end{abstract}

Conclusion: This study didn't find a difference between the fusion rates in L3/4 or L4/5. The pseudarthrosis rate was very high, but good clinical outcomes could be observed so it seems that stable pseudarthrosis after lumbar fusion is sufficient to reduce pain.

\section{Introduction}

In 1982 Harms and Rolinger [1] described the transforaminallumbar intercorporal fusion (TLIF) for the treatment of spondylolisthesis. Since 1998 it has been used for lumbar degenerative diseases [2-5]. The aims are the same as for all other types of lumbar fusion: reduction of the lumbar pain with or without radicular symptoms by nerve decompression and rebuilding the segmental stabilization and the intervertebral disc height [1,5-13].

There are a lot of studies that describe a good clinical outcome when intervertebral fusion is done [7,12-20]. Lumbar fusion is defined as a radiographic bridge bone between the both adjacent vertebral bodies. Many reasons and conditions that seems to improve the fusion rate are known [7-10,19,21-36]. The anatomy and biomechanics in each spinal segment is different. To our knowledge there are no published reports that investigated if there is a difference in fusion according to the addressed segment. This study compared the fusion rates in L3/4 and $\mathrm{L} 4 / 5$ and the clinical outcome after fusion.

\section{Materials and methods}

This retrospective study included patients who were treated by transforaminal lumbar interbody fusion from 2009-2012 in the orthopaedic and trauma surgery at St. Marienkrankenhaus hospital in Ludwigshafen by the chief physician and two senior physicians. The indications for the surgery were symptomatic degenerative lumbar diseases. Other inclusion criteria were the minimum age of 18 years, the use of PEEK cage type 'Mobis I' from Signus Medizintechnik $\mathrm{GmbH}$ (Alzenau) in Germany and a follow up radiography at least one year after surgery. The surgical technique was based on the publication by Harms and Jeszenszky [5] in 1998. The surgeons used local autografts for the interbody fusion. In contrast to Harms [5] they did no posterolateral fusion and performed distraction through the facet screws. All posterior instrumentation was done with several pedicle screw systems, all polyaxial and titanium rods.

The fusion rate of 48 Segments (Group R1: L3/4 = 15, Group $\mathrm{R} 2$ : $\mathrm{L} 4 / 5=33$ ) were radiographically examined with an own created evaluation sheet by one senior physician and a PhD student separately. When they had different fusion results they reached a consense.

The fusion criteria were based on Abbushi [21] and McAffee [14] and included:

- Bone bridge between the both adjacent vertebral bodies in- and/or outside the cage

- No osteolysis around the cage or of the bone inside the cage

- No sagittal motion in lateral flexion-extension radiographs $>3^{\circ}$

- No cage migration

- No screw loosening

${ }^{\star}$ Correspondence to: Sandra Jung, St. Marienkrankenhaus, Orthopaedic and spine surgery, Ludwigshafen on the Rhine, Germany, E-mail: sandra.jung@stmarienkrankenhaus.de

Received: May 02, 2018; Accepted: July 10, 2018; Published: July 23, 2018 
No interbody fusion was defined as no bone bridge between the both adjacent vertebral bodies in- and/or outside the cage, segmental instability or cage migration. But many patients had no bone bridge but also no sagittal motion in the flexion-extension radiographs and no migration of the cage. We defined this as non-fusion, but stable pseudarthrosis.

The clinical outcome preoperative and in the follow up was measured from 39 patients by VAS and ODI and were compared. According to their fusion result they were divided in three groups:

- Group C1: in every segment fusion $(n=8)$

- Group C2: No Fusion in one or both segments $(n=9)$

- Group C3: No Fusion in one or both segments but stable pseudarthrosis $(\mathrm{n}=22)$

The demography of all groups is shown in table 1 and 2 (Figure 1).

\section{Results}

Perioperative complications were found in 7 (17,5 \%) cases: damage of the anterior ligament $(n=1)$, lack location of the screws ( $n$ $=2)$, wrong intraoperative placement of the cage $(n=2)$, intraoperative cage-breaking in the bone $(n=1)$, dural leak with intraoperative cage-breaking in the bone $(\mathrm{n}=1)$. Two patients had no postoperative radiographies, so cage migration was just assessed in 46 segments. Cagebreaking to caudal or cranial was found in 28 segments $(60,9 \%)$, cage dislocation to anterior or posterior was found in 11 segments $(23,9 \%)$ and cage rotation to right or left was found in 14 segments $(29,2 \%)$. There were screw loosening in 7 segments $(14,6 \%)$ postoperative (Figures 2 and 3).

For the comparison of fusion rate between L3/4 and L4/5 48 segments from 40 patients were examined: L3/4 $(n=7), L 4 / 5(n=$ 25) and L3-5 $(\mathrm{n}=8)$. The fusion rate in L3/4 was 5 from 15 segments $(33,3 \%)$ and in L4/5 5 from 33 segments $(15,2 \%)$ (Table 3$)$. We found no correlation between fusion and segment. The Odds Ratio $(\mathrm{OR}=$ 0,36 ) showed that the chance for fusion in $\mathrm{L} 4 / 5$ is smaller than in $\mathrm{L} 3 / 4$.

The clinical evaluation showed an average improvement in VAS of 4,5 (6,6-8,1 preoperative to $2,5-2,9$ in the follow-up). The ODI showed an average improvement of $31,1 \%(52,9-42,2 \%$ to $19,2-14,8 \%)$. There was a significant difference between preoperative VAS and ODI to follow-up. The clinical outcome compared to the fusion rate of the groups C1-3 (fusion, non-fusion, non-fusion but stable pseudarthrosis) showed no significant deviation.

Table 1. Demographics of the patients for radiographic examination

\begin{tabular}{|l|c|c|c|}
\hline \multicolumn{1}{|l|}{} & Average & Minimum & \\
\hline $\begin{array}{l}\text { Group R1 (n= 15) } \\
\mathbf{m}=\mathbf{8} \\
\mathbf{w}=\mathbf{7}\end{array}$ & & & \\
\hline Age at surgery (years) & & & \\
\hline Time from surgery to radiographic examination (months) & 24,8 & 8,4 & 51 \\
\hline $\begin{array}{l}\text { Group R2 (n= 33) } \\
\mathbf{m}=\mathbf{1 8} \\
\mathbf{w}=\mathbf{1 5}\end{array}$ & & 9,5 & 12 \\
\hline Age at surgery (years) & & & \\
\hline Time from surgery to radiographic examination (months) & 67,5 & & \\
\hline
\end{tabular}

Time from surgery to radiographic examination (months) 28,7

${ }^{* 1} \mathrm{SD}$ : Standard Deviation

Table 2. Demographics of the patients for the clinical examination

\begin{tabular}{|c|c|c|c|c|c|}
\hline & Average & SD $^{1}$ & Minimum & Median & Maximum \\
\hline \multicolumn{6}{|l|}{$\begin{array}{l}\text { Group C1 }(\mathrm{n}=8) \\
\mathrm{m}=4 \\
\mathrm{w}=4\end{array}$} \\
\hline Age at surgery (years) & 64,3 & 7,3 & 51 & 65 & 75 \\
\hline Time from surgery to clinical examination (months) & 25,1 & 10,6 & 13 & 20,5 & 46 \\
\hline Time from surgery to radiographic examination (months) & 25,4 & 10,7 & 13 & 21 & 46 \\
\hline \multicolumn{6}{|l|}{$\begin{array}{l}\text { Group C2 }(n=9) \\
m=6 \\
w=3\end{array}$} \\
\hline Age at surgery (years) & 69,3 & 6,4 & 54 & 73 & 75 \\
\hline Time from surgery to clinical examination (months) & 28,2 & 9,2 & 14 & 30 & 42 \\
\hline Time from surgery to radiographic examination (months) & 28,3 & 9,2 & 14 & 31 & 42 \\
\hline \multicolumn{6}{|l|}{$\begin{array}{l}\text { Group C3 }(n=22) \\
m=10 \\
w=12\end{array}$} \\
\hline Age at surgery (years) & 67,3 & 8 & 52 & 68,5 & 82 \\
\hline Time from surgery to clinical examination (months) & 26,5 & 10,6 & 12 & 25 & 47 \\
\hline Time from surgery to radiographic examination (months) & 27,4 & 10,9 & 12 & 25 & 47 \\
\hline
\end{tabular}

Table 3. Fusion rates

\begin{tabular}{|c|c|c|c|c|}
\hline Segment & Number of Segments & non-Fusion & Fusion & Odds Ratio \\
\hline L3/4 & 15 & $10(66,7 \%)$ & $5(33,3 \%)$ & Ref. \\
\hline L4/5 & 33 & $28(84,8 \%)$ & $5(15,2 \%)$ & $0,36(0,08-1,57)$ \\
\hline total & 48 & $38(79,2 \%)$ & $10(20,8 \%)$ & - \\
\hline
\end{tabular}



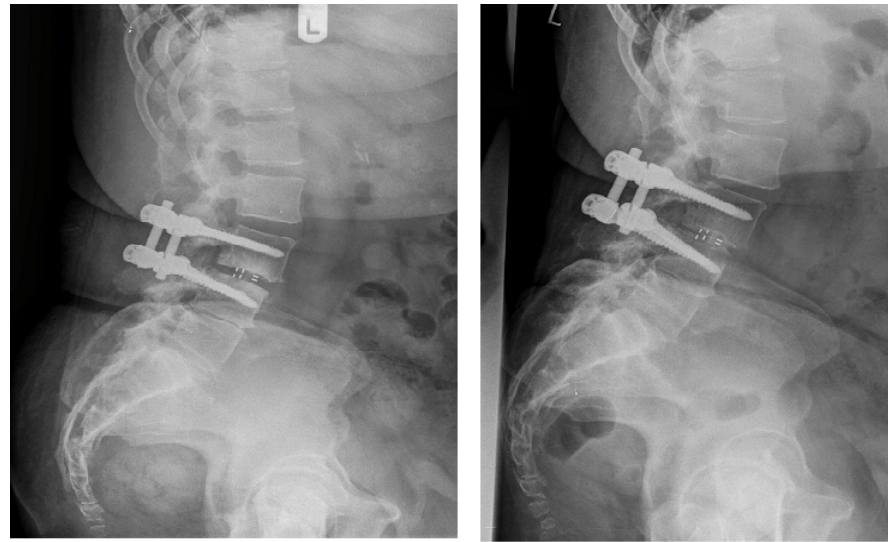

Figure 1. Left post-operative after surgery; right at least one year after surgery

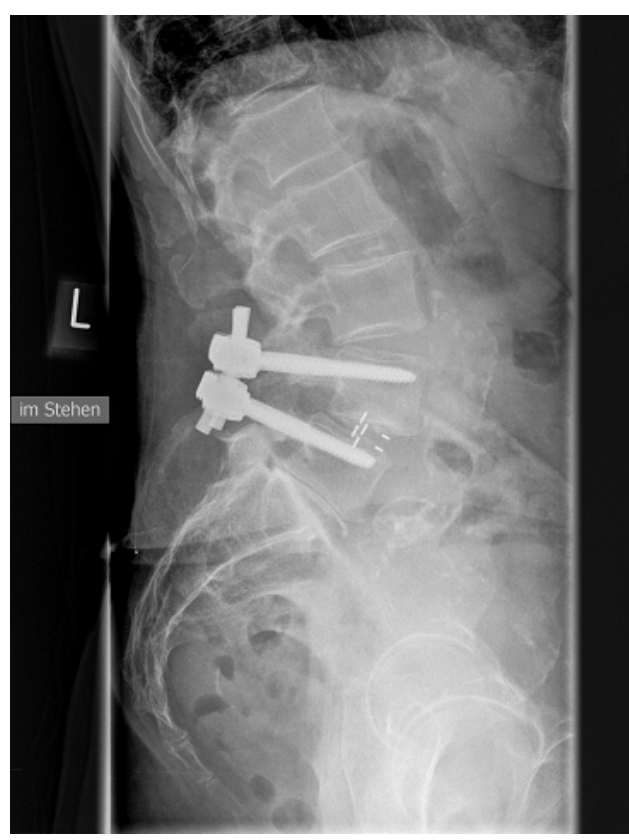

Figure 2. Cage breaking in the F/U radiography

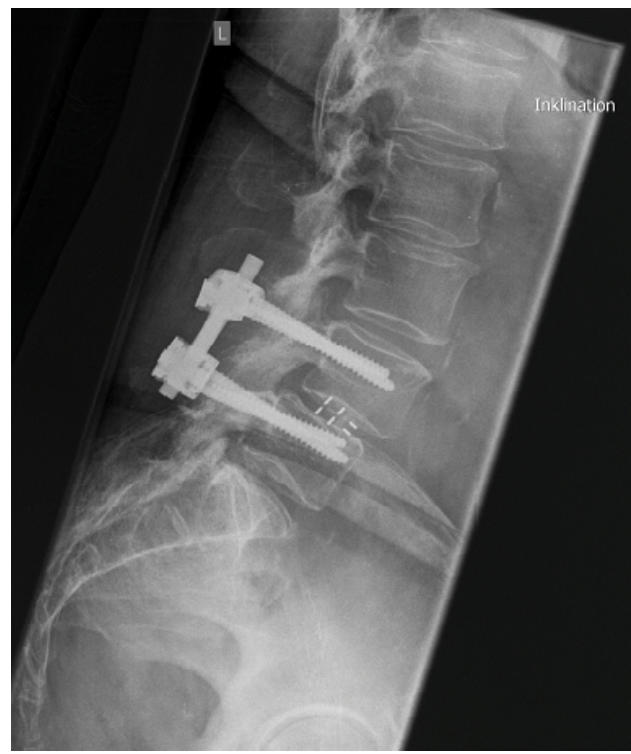

Figure 3. Screw loosening in the upper screws
Group C1 and Group C3 was also compared. There was no significant difference between the clinical outcome.

\section{Discussion}

The diverse lordosis in each segment and the gravity are responsible for the different anatomy and biomechanics in the spine. Lumbar fusion helps to improve the pain and the clinical outcome [7,12-20]. It is necessary to know all the reasons and conditions that enhance the probability for interbody fusion. This study investigated if there is a difference in fusion according to the addressed segment. We found no significant difference between the segment $\mathrm{L} 3 / 4$ or $\mathrm{L} 4 / 5$ in fusion rate. But the total fusion rate was just $20,8 \%$. Compared to other studies this is very low. The literature describes fusion rates of $90 \%[2-4,7,8,18$ $20,22,23,25,37-44]$. So, it's difficult to make an adequate statement if the segment is a factor for reaching interbody fusion.

A meaningful reason for the low fusion rate was the limited patient rate of the study, especially for the L3/4 group. We didn't evaluate co-factors like diabetes, NSAR-taking, smoking, spondylodiscitis, rheumatoid arthritis, preceded fusion and/or revisions [7,10,24-31]. The patient population was inhomogeneous. Another factor that assist a lower fusion rate is the age of the patients, results in lower bone mineralization and higher comorbidities $[7,8,32-36]$. The age in this study was $67,7 \pm 8,4$ years (L3/4) and 67,5 $\pm 6,6$ (L4/5) years. Wu et al. [2] had an average age of 48,7 years.

The TLIF-surgeries in this study were the first in the surgeon's career. Maybe in the beginning they didn't realize the optimal technique. For example, it is important to remove the whole disc [45] and do sufficient decortication [7-9,19,22,23].

The surgeons just used local spongiosa to refill the PEEK cages. They didn't use tricalcium phosphonate, bmp's or AGF's. But there is no evidence that the use of this materials promises a better fusion rate $[23,44]$.

The most important factor for the low fusion rate in this study was apparently the strict fusion criteria. The fusion criteria differ depending on the study so the comparison with other studies is very difficult $[2,21,46,47]$. This study used the criteria of Abbushi et al. [21] and McAffee et al. [14] and defined a stable pseudarthrosis.

Lumbar interbody fusion helps to reduce pain [7,12-20]. In this study the fusion rate was very low, but $87,2 \%$ showed an improved clinical outcome. There was no significant difference between the fusion rate and the clinical outcome. It was very noticeable that the pseudarthrosis rate was $56,4 \%$. Other studies have shown a rate of $2-10 \%[5,17,20,43,48]$.

\section{Conclusion}

This study didn't find a difference between the fusion rates in L3/4 or L4/5. There was a smaller chance for reaching interbody fusion in L4/5 than in L3/4. Many reasons could influence the fusion rate. There is no standard for analysing interbody fusion. Very strict criteria were used and definition of a stable pseudarthrosis was done. This pseudarthrosis rate was very high, but good clinical outcomes could be observed, so it seems that stable pseudarthrosis after lumbar fusion is sufficient to reduce pain [49-51]. A mass of fibrocartilaginous tissues in- and outside the cage is obviously sufficient instead of interbody bone bridging to improve pain [52-54]. 


\section{References}

1. Harms J, Rolinger H (1982) [A one-stager procedure in operative treatment of spondylolistheses: dorsal traction-reposition and anterior fusion (author's transl)]. Z Orthop Ihre Grenzgeb 120: 343-347. [Crossref]

2. Wu RH, Fraser JF, Härtl R (2010) Minimal Access Versus Open Transforaminal Lumbar Interbody Fusion: meta-analysis of fusion. Spine (Phila. Pa. 1976) 35: 2273 2281. [Crossref]

3. Cutler AR, Siddiqui S, Mohan AL, Hillard VH, Cerabona F, et al. (2006) Comparison of polyetheretherketone cages with femoral cortical bone allograft as a single-piece interbody spacer in transforaminal lumbar interbody fusion. J Neurosurg Spine 5: 534539. [Crossref]

4. Houten JK, Post NH, Dryer JW, Errico TJ (2006) Clinical and radiographically/ neuroimaging documented outcome in transforaminal lumbar interbody fusion. Neurosurg Focus 20: E8. [Crossref]

5. Harms JG, Jeszenszky D (1998) Die posteriore, lumbale, interkorporelle Fusion in unilateraler transforaminaler Technik. Oper Orthop Traumatol 10: 90-102, 1998. [Crossref]

6. Diedrich O, Kraft CN, Bertram R, Wagner U, Schmitt O (2000) Die dorsale lumbale interkorporelle Implantation von Cages zur Stabilisierung von segmentalen Wirbelsäuleninstabilitäten. Zeitschrift für Orthopa"die und ihre Grenzgebiete 138: $162-8$.

7. Lowe TG, Tahernia a D, O'Brien MF, Smith DA (2002) Unilateral transforaminal posterior lumbar interbody fusion (TLIF): indications, technique, and 2-year results. $J$ Spinal Disord Tech 15: 31-8. [Crossref]

8. Taneichi H, Suda K, Kajino T, Matsumura A, Moridaira H, et al. (2006) Unilateral transforaminal lumbar interbody fusion and bilateral anterior-column fixation with two Brantigan I/F cages per level: clinical outcomes during a minimum 2-year follow-up period. J Neurosurg Spine 4: 198-205. [Crossref]

9. Rosenberg WS, Mummaneni PV (2001) Transforaminal lumbar interbody fusion: technique, complications, and early results. Neurosurgery 48: 569-74. [Crossref]

10. Suk SI, Lee CK, Kim WJ, Lee JH, Cho KJ, et al. (1997) Adding posterior lumbar interbody fusion to pedicle screw fixation and posterolateral fusion after decompression in spondylolytic spondylolisthesis. Spine (Phila. Pa. 1976). 22: 210-9. [Crossref]

11. CLOWARD RB (1953) The treatment of ruptured lumbar intervertebral discs by vertebral body fusion. I. Indications, operative technique, after care. J Neurosurg 10: 154-168. [Crossref]

12. Cloward RB (1985) Posterior lumbar interbody fusion updated. Clin Orthop Relat Res: 16-19. [Crossref]

13. Brantigan JW, Steffee a D, Lewis ML, Quinn LM, Persenaire JM (2000) Lumbar interbody fusion using the Brantigan $\mathrm{I} / \mathrm{F}$ cage for posterior lumbar interbody fusion and the variable pedicle screw placement system: two-year results from a Food and Drug Administration investigational device exemption clinical trial. Spine (Phila. Pa. 1976) 25: 1437-46. [Crossref]

14. McAfee PC, DeVine JG, Chaput CD, Prybis BG, Fedder IL, et al. The indications for interbody fusion cages in the treatment of spondylolisthesis: analysis of 120 cases. Spine (Phila. Pa. 1976) 30: S60-5. [Crossref]

15. Fritzell P, Hägg O, Wessberg P, Nordwall A, Swedish Lumbar Spine Study Group (2001) 2001 Volvo Award Winner in Clinical Studies: Lumbar fusion versus nonsurgical treatment for chronic low back pain: a multicenter randomized controlled trial from the Swedish Lumbar Spine Study Group. Spine (Phila. Pa. 1976) 26: 2521 32. [Crossref]

16. Buttermann GR, Garvey TA, Hunt AF, Transfeldt EE, Bradford DS, et al. (1998) Lumbar fusion results related to diagnosis. Spine (Phila Pa 1976) 23: 116-127. [Crossref]

17. Hackenberg L, Halm H, Bullmann V, Vieth V, Schneider M, et al. (2005) Transforaminal lumbar interbody fusion: a safe technique with satisfactory three to five year results. Eur Spine J 14: 551-558. [Crossref]

18. Yan DL, Pei FX, Li J, Soo CL (2008) Comparative study of PILF and TLIF treatment in adult degenerative spondylolisthesis. Eur Spine J 17: 1311-1316. [Crossref]

19. Lauber S, Schulte TL, Liljenqvist U, Halm H, Hackenberg L (2006) Clinical and radiologic 2-4-year results of transforaminal lumbar interbody fusion in degenerative and isthmic spondylolisthesis grades 1 and 2. Spine (Phila. Pa. 1976) 31: 1693-8. [Crossref]

20. Potter BK, Freedman BA, Verwiebe EG, Hall JM, Polly DW Jr, et al. (2005) Transforaminal lumbar interbody fusion: clinical and radiographic results and complications in 100 consecutive patients. J Spinal Disord Tech 18: 337-346. [Crossref]
21. Abbushi A, Cabraja M, Thomale UW, Woiciechowsky C, Kroppenstedt SN (2009) The influence of cage positioning and cage type on cage migration and fusion rates in patients with monosegmental posterior lumbar interbody fusion and posterior fixation. Eur Spine J 18: 1621-1628. [Crossref]

22. Mummaneni PV, Pan J, Haid RW, Rodts GE (2004) Contribution of recombinant human bone morphogenetic protein-2 to the rapid creation of interbody fusion when used in transforaminal lumbar interbody fusion: a preliminary report. $J$ Neurosurg Spine 1: 19-23. [Crossref]

23. Villavicencio AT, Burneikiene S, Nelson EL, Bulsara KR, Favors M, et al. (2005) Safety of transforaminal lumbar interbody fusion and intervertebral recombinant human bone morphogenetic protein-2. J Neurosurg Spine 3: 436-443. [Crossref]

24. Steffee AD, Sitkowski DJ (1988) Posterior lumbar interbody fusion and plates. Clin Orthop Relat Res 227: 99-102. [Crossref]

25. Hee HT, Majd ME, Holt RT, Myers L (2003) Do autologous growth factors enhance transforaminal lumbar interbody fusion? Eur Spine J 12: 400-407. [Crossref]

26. Buckwalter JA, Glimcher MJ, Cooper RR, Recker R (1996) Bone biology. II Formation, form, modeling, remodeling, and regulation of cell function. Instr Course Lect 45: 387-399. [Crossref]

27. Lim TH, Kwon H, Jeon CH, Kim JG, Sokolowski M, et al. (2001) Effect of endplate conditions and bone mineral density on the compressive strength of the graft-endplate interface in anterior cervical spine fusion. Spine (Phila. Pa. 1976). 26: 951-6. [Crossref]

28. Shirado O, Zdeblick TA, McAfee PC, Warden KE (1991) Biomechanical evaluation of methods of posterior stabilization of the spine and posterior lumbar interbody arthrodesis for lumbosacral isthmic spondylolisthesis. A calf-spine model. J Bone Joint Surg Am 73: 518-526. [Crossref]

29. Frymoyer JW, Matteri RE, Hanley EN, Kuhlmann D, Howe J (1978) Failed lumbar disc surgery requiring second operation. A long-term follow-up study. Spine (Phila Pa. 1976). 3: 7-11. [Crossref]

30. Tandon V, Campbell F, Ross ER (1999) Posterior lumbar interbody fusion. Association between disability and psychological disturbance in noncompensation patients. Spine (Phila Pa 1976) 24: 1833-1838. [Crossref]

31. Burton CV, Kirkaldy-Willis WH, Yong-Hing K, Heithoff KB (1981) Causes of failure of surgery on the lumbar spine. Clin Orthop Relat Res : 191-199. [Crossref]

32. Kim SM, Rhee W, Ha S, Lim JH, Jang IT (2014) Influence of alendronate and endplate degeneration to single level posterior lumbar spinal interbody fusion. Korean $J$ Spine 11: 221-226. [Crossref]

33. Tempel ZJ, Gandhoke GS, Okonkwo DO, Kanter AS (2015) Impaired bone minera density as a predictor of graft subsidence following minimally invasive transpsoas lateral lumbar interbody fusion. Eur Spine J 24 Suppl 3: 414-419. [Crossref]

34. Rouben D, Casnellie M, Ferguson M (2011) Long-term durability of minimal invasive posterior transforaminal lumbar interbody fusion: a clinical and radiographic followup. J Spinal Disord Tech 24: 288-296. [Crossref]

35. Schulte TL, Bullmann V, Lerner T, Schneider M, Marquardt B, et al. (2006) [Lumbar spinal stenosis]. Orthopade 35: 675-692. [Crossref]

36. Katz JN, Stucki G, Lipson SJ, Fossel AH, Grobler LJ, et al. (1999) Predictors of surgical outcome in degenerative lumbar spinal stenosis. Spine (Phila Pa 1976) 24 2229-2233. [Crossref]

37. Anand N, Hamilton JF, Perri B, Miraliakbar H, Goldstein T (2006) Cantilever TLIF with structural allograft and RhBMP2 for correction and maintenance of segmental sagittal lordosis: long-term clinical, radiographic, and functional outcome. Spine (Phila. Pa. 1976) 31: E748-53. [Crossref]

38. Hackenberg L, Liljenqvist U, Halm H, Winkelmann W (2001) Occlusion of the left common iliac artery and consecutive thromboembolism of the left popliteal artery following anterior lumbar interbody fusion. J Spinal Disord 14: 365-368. [Crossref]

39. Hallett A, Huntley JS, Gibson JNA (2007) Foraminal stenosis and single-level degenerative disc disease: a randomized controlled trial comparing decompression with decompression and instrumented fusion. Spine (Phila. Pa. 1976) 32: 1375-80. [Crossref]

40. Kuklo TR, Rosner MK, Polly DW Jr (2004) Computerized tomography evaluation of a resorbable implant after transforaminal lumbar interbody fusion. Neurosurg Focus 16 : E10. [Crossref]

41. Lanman TH, Hopkins TJ (2004) Lumbar interbody fusion after treatment with recombinant human bone morphogenetic protein-2 added to poly(L-lactide-co-D,Llactide) bioresorbable implants. Neurosurg Focus 16: E9. [Crossref] 
42. Rivet DJ, Jeck D, Brennan J, Epstein A, Lauryssen C (2004) Clinical outcomes and complications associated with pedicle screw fixation-augmented lumbar interbody fusion. J Neurosurg Spine 1: 261-6. [Crossref]

43. Salehi SA, Tawk R, Ganju A, LaMarca F, Liu JC, et al. (2004) Transforaminal Lumbar Interbody Fusion: Surgical Technique and Results in 24 Patients. Neurosurgery 54: 368-374. [Crossref]

44. Vaidya R, Weir R, Sethi A, Meisterling S, Hakeos W, et al. (2007) Interbody fusion with allograft and rhBMP-2 leads to consistent fusion but early subsidence. $J$ Bone Joint Surg Br 89: 342-345. [Crossref]

45. Closkey RF, Parsons JR, Lee CK, Blacksin MF, Zimmerman MC (1993) Mechanics of interbody spinal fusion. Analysis of critical bone graft area. Spine (Phila Pa 1976) 18: 1011-1015. [Crossref]

46. McAfee PC (1999) Interbody fusion cages in reconstructive operations on the spine. $J$ Bone Joint Surg Am 81: 859-880. [Crossref]

47. Lenke LG, Bridwell KH, Bullis D, Betz RR, Baldus C, et al. (1992) Results of in situ fusion for isthmic spondylolisthesis. $J$ Spinal Disord 5: 433-442. [Crossref]

48. Hee HT, Castro FP Jr, Majd ME, Holt RT, Myers L (2001) Anterior/posterior lumbar fusion versus transforaminal lumbar interbody fusion: analysis of complications and predictive factors. $J$ Spinal Disord 14: 533-540. [Crossref]
49. Herkowitz HN, Kurz LT (1991) Degenerative lumbar spondylolisthesis with spinal stenosis. A prospective study comparing decompression with decompression and intertransverse process arthrodesis. J Bone Joint Surg Am 73: 802-808. [Crossref]

50. DePalma AF, Rothman RH (1968) The nature of pseudarthrosis. Clin Orthop Relat Res 59: 113-118. [Crossref]

51. Faundez AA, Schwender JD, Safriel Y, Gilbert TJ, Mehbod AA, et al. (2009) Clinical and radiological outcome of anterior-posterior fusion versus transforaminal lumbar interbody fusion for symptomatic disc degeneration: a retrospective comparative study of 133 patients. Eur Spine J 18: 203-211. [Crossref]

52. Fischgrund JS, Mackay M, Herkowitz HN, Brower R, Montgomery DM, et al. 1997 Volvo Award winner in clinical studies. Degenerative lumbar spondylolisthesis with spinal stenosis: a prospective, randomized study comparing decompressive laminectomy and arthrodesis with and without spinal instrumentation. Spine (Phila. Pa. 1976) 22: 2807-12. [Crossref]

53. Kornblum MB, Fischgrund JS, Herkowitz HN, Abraham DA, Berkower DL, et al. (2004) Degenerative lumbar spondylolisthesis with spinal stenosis: a prospective longterm study comparing fusion and pseudarthrosis. Spine (Phila. Pa. 1976). 29: 726-733. [Crossref]

54. Cloward RB (1981) Spondylolisthesis: treatment by laminectomy and posterior interbody fusion. Clin Orthop Relat Res: 74-82. [Crossref]

Copyright: $@$ 2018 Jung S. This is an open-access article distributed under the terms of the Creative Commons Attribution License, which permits unrestricted use, distribution, and reproduction in any medium, provided the original author and source are credited. 